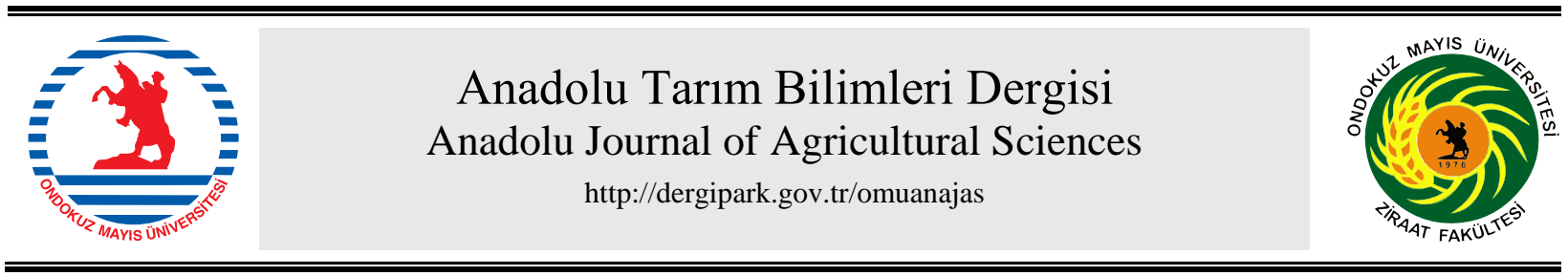

\title{
Araştırma/Research
}

Anadolu Tarım Bilim. Derg./Anadolu J Agr Sci, 35 (2020) ISSN: 1308-8750 (Print) 1308-8769 (Online) doi: 10.7161/omuanajas.747347

\section{Yapraktan uygulanan farklı organik gübrelerin Mentha x piperita L. ve Mentha spicata L. türlerinin tarımsal ve kalite özelliklerine etkisi}

\author{
๑Mustafa Can ${ }^{\mathrm{a}^{*}}$, ๑Duran Katar ${ }^{\mathrm{b}}$ \\ ${ }^{a}$ Eskişsehir Osmangazi Üniversitesi, Fen Bilimleri Enstitüsü, Eskişehir, Türkiye \\ ${ }^{b}$ Eskişehir Osmangazi Üniversitesi, Ziraat Fakültesi, Tarla Bitkileri Bölümü, Eskişehir, Türkiye
}

*Sorumlu yazar/corresponding author: mustafican@gmail.com

Geliş/Received 03/06/2020 Kabul/Accepted 16/07/2020

\begin{abstract}
ÖZET
Çalışmada Lifebac-Np (3.00 L da-1), Bactoguard (3.00 L da-1) ve Humıca Power $\left(0.25 \mathrm{~L} \mathrm{da}^{-1}\right)$ isimli 3 organik gübre kullanılmıştır. 2018 ve 2019 vejetasyon dönemindeki biçimler birleştirilerek ortalama bitki boyu ve uçucu yağ oranı, toplam taze ve kuru herba, kuru yaprak ve uçucu yağ verimleri ile uçucu yağın bileşenleri incelenmiştir. Araştırmada iki yılın ortalamasına göre Mentha x piperita ve Mentha spicata'da toplam kuru yaprak verimi sirasiyla $230.01-361.35 \mathrm{~kg} \mathrm{da}^{-1}$ ve 266.56-333.86 kg da-1 arasinda, toplam uçucu yağ verimi ise sırasıyla 5.18-8.28 $\mathrm{L} \mathrm{da}^{-1}$ ve 4.77-6.45 $\mathrm{L} \mathrm{da}^{-1}$ arasında değişmiştir. Uçucu yağ oranları Mentha x piperita'da \% 2.19-2.24 ve Mentha spicata'da ise \% 1.79-1.94 arasında belirlenmiştir. Mentha x piperita ve Mentha spicata'da bitki boyu, toplam taze ve kuru herba verimi, kuru yaprak verimi ve uçucu yağ verimi organik gübre uygulamaları ile önemli derecede artmıştır. Uçucu yağın ana bileşenleri Mentha x piperita'da menthol ve menthon, Mentha spicata'da ise carvone ve limonene olarak tespit edilmiştir. En yüksek menthol oranı (\% 44.86) ile en yüksek carvone oranı (\% 58.69) Humıca Power uygulamasından elde edilmiştir. Her iki nane türünde en yüksek kuru yaprak ve uçucu yağ verimleri Lifebac-Np uygulamasından alınmıştır. Ancak uygulanan organik gübreler arasında toplam kuru yaprak ve uçucu yağ verimi bakımından Mentha $x$ piperita'da istatistiksel olarak önemli farklılık görülürken, Mentha spicata'da önemli farkl1lık görülmemiştir.
\end{abstract}

Effect of different organic fertilizer applied from foliar on agricultural and quality characteristics of Mentha x piperita L. and Mentha spicata L. species

\section{ABSTRACT}

In the study, 3 organic fertilizers called Lifebac-Np (3.00 L da-1), Bactoguard (3.00 L da $\left.{ }^{-1}\right)$ and Humica Power $\left(0.25 \mathrm{~L} \mathrm{da}^{-1}\right)$ were used. Tharvests in the vegetation period of 2018 - 2019 were combined and the average plant height and essential oil content, total fresh and dry herbage, dry leaf and essential oil yields and the composition of the essential oil were examined. According to the average of two years in the research, the total dry leaf yield ranged from $230.01-361.35 \mathrm{~kg} \mathrm{da}^{-1}$ and $266.56-333.86 \mathrm{~kg} \mathrm{da}^{-1}$ in Mentha $x$ piperita and Mentha spicata respectively. Also, the total essential oil yield ranged from $5.18-8.28 \mathrm{~L} \mathrm{da}^{-1}$ ve 4.77-6.45 $\mathrm{L} \mathrm{da}^{-1}$ in Mentha x piperita and Mentha spicata respectively. Essential oil contents were determined between 2.19-2.24\% in Mentha x piperita and 1.79-1.94\% in Mentha spicata. Plant height, total fresh and dry herb yield, dry leaf yield and essential oil yield increased significantly with organic fertilizer applications in Mentha x piperita and Mentha spicata. The main components of the essential oil were identified as menthol and menthon in Mentha $x$ piperita and carvone and limonene in Mentha spicata. The highest values menthol (44.86\%) and carvone (58.69\%) were obtained from Humica Power application. As a result, the highest dry leaf and essential oil yields in both mint species were obtained from Lifebac-Np application. However, while there was a statistically significant difference in Mentha $x$ piperita among the organic fertilizers applied in terms of total dry leaf and essential oil yield, there was no significant difference in Mentha spicata.
Anahtar Sözcükler: Mentha x piperita L. Mentha spicata $\mathrm{L}$. Organik gübre Yapraktan uygulama Verim

Uçucu yağ bileşimi

Keywords:

Mentha x piperita L. Mentha spicata L. Organic fertilizer Applied from foliar Yield

Essential oil composition

(c) OMU ANAJAS 2020 


\section{Giriş}

Çok yıllık, otsu ve sürünücü gövdelere sahip olan Mentha spp. türleri genel bir isim olarak nane ismiyle tanımlanırlar. Lamiaceae familyasında yer alan nane bitkisi aynı zamanda değerli bir baharat ve uçucu yağ bitkisidir. Anavatanı Orta Avrupa ve Asya olmakla birlikte, hemen hemen dünyanın her bölgesinde yayılış gösteren geniş bir tür zenginliğine sahiptir (Baytop, 1992). Türkiye'de nanenin yedi türüne (Mentha pulegium, Mentha arvensis, Mentha aquatica, Mentha $x$ piperita, Mentha longifolia, Mentha suaveolens, Mentha spicata) ait 12 takson yayılış göstermektedir (Davis, 1982). Dünya'da kültürü yapılan en önemli 3 nane türü Mentha x piperita, Mentha spicata ve Mentha arvensis' tir. Uçucu yağları menthol ihtiva etmesinden dolayı Mentha arvensis ve Mentha x piperita Hindistan, Çin ve $\mathrm{ABD}$ gibi ülkelerde yaygın olarak üretilmektedir (Telci ve Şahbaz, 2005a).

Türkiye'de daha çok baharat olarak kullanılan ve uçucu yağı karvon bakımından zengin (\% 40-80) tür olan Mentha spicata türünün kültürü yapılmaktadır. Mentha x piperita'nın kuru yapraklarında \% 1.5-3.5 oranında uçucu yağ bulunmakta, uçucu yağın ana bileşenlerini ise \% 45-70 oranında menthol ve \% 8-24 oranında menthon olușturmaktadır. Nane, baharat olarak çorbalara, salatalara, kızartmalara ve sıcak yemeklere iştah açmak ve lezzet vermek için katılmakta, eczacilıkta ise antiseptik, anastezik, serinletici, ferahlatıcı, yatıştırıcı, gaz söktürücü, bulantı kesici ve ishal önleyici ilaçların yapımında kullanılmaktadır (Baydar, 2016).

Türkiye'de 2018 y1l verilerine göre 14.511 ton nane üretimi yapılmıştır (TÜIKK, 2019). Bu miktar çoğunlukla baharat olarak tüketilmektedir. Türkiye'de nane uçucu yağı ihtiyacı dış alımla karşılanmaktadır. Zira, Mentha $x$ piperita ve diğer nane türlerinden elde edilen uçucu yă toplamı (terpeni alınmış ve terpeni alınmamış dahil) dikkate alındığında, Türkiye'de 2018 yılında 122.8 ton (4.3 milyon dolar) nane uçucu yağı ithalatının ve 245.7 ton (6.9 milyon dolar) menthol ithalatının yapıldığ görülmektedir (Anonim, 2019).

Tıbbi ve aromatik bitkilerin verim ve kalitesi üzerine gübrelemenin önemli derecede etkisi olduğu yapılan birçok araştırmada bildirilmiştir (Nurzynska-Wierdak, 2013; Özyiğit ve ark., 2016; Can, 2020). Bununla birlikte, kimyasal gübrelerin uzun süreli kullanımı, toprak organik maddesinin tükenmesine, toprak yapısının bozulmasına ve çevre kirliliği sorunlarına (Rao, 2001) ve bitki-mikroorganizma arasındaki doğal dengeyi ve toprak yapısını da olumsuz yönde etkileyerek biyolojik dengenin bozulmasina neden olmaktadır (Vessey, 2003). Ayrıca bitkilerde yüksek miktarlarda kullanılan azot, yanlış teknik uygulamalarla bir araya geldiğinde yıkanarak yüzey sularına veya yeraltı su kaynaklarına karışmakta (Nektarios et al., 2014) ve nitrat birikimine sebep olabilmektedir.

Dünya'da organik üretimi yapılan bitkilere ve droglara olan ilgi ve talep her geçen gün artmaktadır. Bu yüzden özellikle nane gibi doğrudan yaprağı tüketilen bitkilerde kimyasal gübrelerin yanı sıra organik gübrelerin de etkinliğinin araştırılması büyük önem arz etmektedir. Zira organik gübreler, kimyasal gübreye aşırı bağımlılığı azaltabilecek besinleri sağlama özelliğine sahip çevre dostu girdilerdir (Bajeli et al., 2016). Türkiye'de organik, organomineral ve mikrobiyal gübrelerin kullanımı gerek temin edilebilirliğinin artması gerekse uygulanabilirliğinin kolay olması nedeniyle yaygınlaşmaya başlamıştır. Ancak söz konusu materyallerin etkinlik düzeyleri ve yeterlilik durumları ile ilgili yapılan çalışmalar oldukça sinirlidir.

$\mathrm{Bu}$ çalışmada; yapraktan uygulanan farklı organik gübrelerin Mentha $x$ piperita ve Mentha spicata türlerinin tarımsal ve kalite özellikleri üzerine etkisinin belirlenmesi amaçlanmıştır.

\section{Materyal ve Yöntem}

$\mathrm{Bu}$ araştırma, yapraktan uygulanan organik gübrelerin Mentha $\mathrm{x}$ piperita ve Mentha spicata türlerinin tarımsal ve kalite özelliklerine etkisinin belirlenmesi amacıyla, 2017-2019 yıllarında Uşak ekolojik koşullarında yürütülmüştür. Denemenin yürütüldüğü 2017-2019 yılları ile uzun yıllara ait iklim değerleri Çizelge 1'de verilmiştir. Uşak ilinde uzun yıllar (1986-2016) yıllık yağış miktarı ortalaması 510.6 mm'dir. 2017, 2018 ve 2019 yıllarına ait toplam yağış miktarları sirasiyla $555.2 \mathrm{~mm}, 725.0 \mathrm{~mm}$ ve $414.3 \mathrm{~mm}$ olmuştur. 2018 yılı ortalama sicaklık değeri $14.1{ }^{\circ} \mathrm{C}$ iken, 2019 yılında $13.6{ }^{\circ} \mathrm{C}^{\prime}$ ye düşmüştür. 2018 ve 2019 yıllarında ortalama nispi nemin sirasıyla \% 61.1 ve \% 59.3 olarak gerçekleştiği görülmektedir (Çizelge 1). Çalışmanın yürütüldüğg̈ deneme alanı topraklarının killi-tınlı bünyeye sahip, hafif alkalin karakterde, tuzsuz, orta kireçli, organik madde miktarı açısından yetersiz ve toplam azotça fakir, yarayışlı fosfor içeriği az ve potasyum içeriği yeterli bulunmuştur (Çizelge 2).

Eskişehir Osmangazi Üniversitesi Ziraat Fakültesi deneme tarlasinda yer alan Mentha x piperita ve Mentha spicata türlerine ait plantasyondan 8-10 cm uzunlukta çelikler alınmış ve Uşak ilindeki açık alanda 1:1 oranında tarla toprağı+ince dere kumu ile hazırlanan köklendirme ortamında, kasalar içerisinde köklendirilmiştir. Plantasyondan 24.05.2017 tarihinde alınan çelikler, köklendirme ortamına 25.05.2017 tarihinde dikilmiş ve yaklaşık 1.5 ay sonra tarlaya şaşırtılacak duruma gelmiştir. Bu şekilde köklenen 
Çizelge 1. Deneme alanının 2017-2019 ve uzun yıllar sıcaklık, yağış ve nisbi nem değerleri

Table 1. Temperature, precipitation and relative humidity values of the experiment area for 2016-2017 and many years

\begin{tabular}{|c|c|c|c|c|c|c|c|c|c|c|}
\hline \multirow[t]{2}{*}{ Aylar } & \multicolumn{4}{|c|}{$\begin{array}{l}\text { Toplam Yağış } \\
\text { (mm) }\end{array}$} & \multicolumn{3}{|c|}{$\begin{array}{c}\text { Ortalama Sicaklik } \\
\left({ }^{\circ} \mathrm{C}\right)\end{array}$} & \multicolumn{3}{|c|}{$\begin{array}{c}\text { Ortalama Nispi Nem } \\
\text { (\%) }\end{array}$} \\
\hline & 1986-2016 & 2017 & 2018 & 2019 & 2017 & 2018 & 2019 & 2017 & 2018 & 2019 \\
\hline Ocak & 58.4 & 84.3 & 71.8 & 87.9 & -0.1 & 3.6 & 1.6 & 73.8 & 73.2 & 80.9 \\
\hline Şubat & 58.5 & 11.1 & 63.8 & 17.3 & 4.3 & 6.7 & 5.4 & 65.0 & 73.9 & 65.6 \\
\hline Mart & 51.1 & 37.1 & 76.8 & 20.8 & 8.3 & 9.3 & 7.8 & 59.7 & 67.6 & 58.4 \\
\hline Nisan & 57.7 & 62.9 & 6.4 & 40.1 & 11.1 & 15.4 & 10.5 & 56.4 & 47.5 & 60.4 \\
\hline Mayıs & 43.1 & 100.2 & 102.4 & 36.9 & 15.1 & 17.2 & 16.7 & 61.9 & 61.5 & 55.5 \\
\hline Haziran & 24.1 & 42.3 & 54.6 & 37.3 & 20.1 & 20.2 & 20.9 & 58.7 & 59.4 & 58.6 \\
\hline Temmuz & 15.5 & 1.2 & 58.2 & 8.9 & 25.1 & 23.7 & 22.8 & 41.4 & 49.3 & 47.0 \\
\hline Ağustos & 9.5 & 25.6 & 37.8 & 0.4 & 24.0 & 24.3 & 24.4 & 48.2 & 48.0 & 42.8 \\
\hline Eylül & 17.2 & 31.2 & 0.1 & 22.1 & 21.6 & 20.4 & 19.4 & 39.1 & 46.8 & 52.2 \\
\hline Ekim & 44.9 & 63.3 & 74.1 & 6.4 & 12.9 & 14.8 & 16.6 & 58.3 & 59.1 & 55.3 \\
\hline Kasım & 56.3 & 43.2 & 68.7 & 47.9 & 7.6 & 9.5 & 11.6 & 67.6 & 67.7 & 63.1 \\
\hline Aralık & 74.3 & 52.8 & 110.3 & 88.3 & 5.6 & 3.6 & 5.5 & 75.8 & 79.1 & 71.3 \\
\hline Toplam & 510.6 & 555.2 & 725.0 & 414.3 & - & - & - & - & - & - \\
\hline Ortalama & - & - & - & - & 13.0 & 14.1 & 13.6 & 58.8 & 61.1 & 59.3 \\
\hline
\end{tabular}

Kaynak: Uşak Meteoroloji Müdürlüğü, 2020

Çizelge 2. Deneme alanı toprağının fiziksel ve kimyasal özellikleri

Table 2. Physical and chemical properties of experiment area soil

\begin{tabular}{|c|c|c|c|c|c|c|c|c|c|c|}
\hline $\begin{array}{l}\text { Kil } \\
(\%)\end{array}$ & $\begin{array}{l}\text { Te } \\
\text { (Kill } \\
\text { Silt } \\
\text { (\%) }\end{array}$ & $\begin{array}{l}\text { stür } \\
\text { Tinlı) } \\
\text { Kum } \\
\text { (\%) }\end{array}$ & $\begin{array}{l}\text { İşba } \\
\text { (ml) }\end{array}$ & $\begin{array}{l}\text { Kireç } \\
(\%)\end{array}$ & $\begin{array}{c}\text { Tuz } \\
\text { (mikros/cm) }\end{array}$ & $\begin{array}{l}\text { Toplam } \\
\text { N. (\%) }\end{array}$ & $\begin{array}{c}\text { Yarayış11 } \\
\text { Fosfor } \\
\text { (ppm) }\end{array}$ & $\begin{array}{l}\text { Yarayışlı } \\
\text { Potasyum } \\
\text { (ppm) }\end{array}$ & $\mathrm{pH}$ & $\begin{array}{c}\text { Organik } \\
\text { Madde } \\
(\%)\end{array}$ \\
\hline 38 & 35 & 27 & 53 & 9.9 & 615 & 0.004 & 2.46 & 340 & 7.81 & 0.08 \\
\hline
\end{tabular}

Toprak analizi Uşak İl Tarım ve Orman Müdürlüğü Toprak Analiz Laboratuvarında yapılmıştır.

fideler, Uşak İli Hocalar Köyünde bulunan çiftçi tarlasina $\left(38^{\circ} 35^{\prime} 36.89^{\prime \prime}\right.$ kuzey enlemi ve $29^{\circ} 26^{\prime} 53.77^{\prime \prime}$ doğu boylamı) 24.07 .2017 tarihinde, sira aras $45 \mathrm{~cm}$ ve sira üzeri $30 \mathrm{~cm}$, her parselde 4 sira ve her sirada 12 bitki olacak şekilde dikilmiştir. Denemede parsel boyutları $3.6 \mathrm{~m} \times 1.8 \mathrm{~m}=6.5 \mathrm{~m}^{2}$ olarak alınmıştır. Deneme, Tesadüf Bloklarında Bölünmüş Parseller Deneme Desenine göre 3 tekrarlamalı kurulmuştur. Denemede ticari olarak satılan Lifebac-Np $\left(3.00 \mathrm{~L} \mathrm{da}^{-1}\right)$, Bactoguard (3.00 L da-1) ve Humica Power $\left(0.25 \mathrm{~L} \mathrm{da}^{-1}\right)$ isimli 3 organik gübre kullanılmıştır. Organik gübrelere ait özellikler Çizelge 3'de verilmiştir. Denemede kullanılan organik gübreler kullanma talimatına uygun olarak iki defada (birincisi ilkbaharda bitkiler 10-15 cm olduğunda, ikincisi ise birinci uygulamadan 20 gün sonra) yapraktan pülverize etmek suretiyle verilmiştir. Birinci biçim sonrası da organik gübreler aynı şekilde yapraktan iki defa daha (birincisi bitkiler 10-15 cm olduğunda, ikincisi ise birinci uygulamadan 20 gün sonra) uygulanmıştır. Deneme alanı damla sulama yöntemi ile 7-10 gün aralıklarda sulanmış, yabancı ot mücadelesi ise elle yapılmıştır. Araştırmada her parselin ilk ve son siraları ile siraların her iki ucundan $0.3 \mathrm{~m}$ kenar tesiri değerlendirme dışı bırakılmıştır. Hasat nane türlerinin çiçeklenme başlangıcında, toprak seviyesinden 5-10 cm yükseklikten biçilmesi suretiyle yapılmıştır. 2017 yılı plantasyonun kuruluş yılı olup, kuruluş yilında Mentha spicata ve Mentha x piperita türlerinde bitki gelişimi normal hasat yapılacak düzeye ulaşamadığından hasat yapılamamıştır. 2018 ve 2019 yıllarında ise çalışmada ikişer biçim alınmış, çalışmada yer alan nane türlerine göre biçim zamanları değişiklik göstermiştir. 2018 y1lında Mentha spicata ve Mentha x piperita türlerinde birinci biçimler sırasıyla 28.06.2018 ve 10.07.2018 tarihinde, ikinci biçimler sırasıyla 08.09.2018 ve 14.09.2018 tarihinde yapılmıştır. 2019 yllinda ise Mentha spicata ve Mentha $x$ piperita türlerinde birinci biçimler surasıyla 04.07.2019 ve 15.07.2019 tarihinde, ikinci biçimler sırasıyla 14.09.2019 ve 21.09.2019 tarihinde tamamlanmıştır. Bu 
makalede 2018 ve 2019 yılı vejetasyon dönemi boyunca yapılan ikişer biçimler birleştirilerek toplam verimler

Çizelge 3. Denemede kullanılan organik gübreler

Table 3. Organic fertilizer used in the experiment verilmiştir.

\begin{tabular}{|c|c|c|}
\hline $\begin{array}{l}\text { Organik } \\
\text { gübre }\end{array}$ & Özellikler & Uygulama Şekli \\
\hline Lifebac-Np & $\begin{array}{l}\text { Doğal bir Bacillus subtilis ve Bacillus megaterium izolatı içeren } \\
\text { sıvı bir mikrobiyal gübredir. }\end{array}$ & $\begin{array}{l}\text { Bir dekar alan için } 3000 \mathrm{ml} \text { ürün } 100 \mathrm{lt} \\
\text { suyla karıştırılır ve yapraktan uygulanır. }\end{array}$ \\
\hline Bactoguard & $\begin{array}{l}\text { Bünyesinde doğal formda organik asit, aminoasit, antioksidan } \\
\text { enzimler ve hormon içeriği bulunan, bitki menşeli sıvı bir organik } \\
\text { gübredir. }\end{array}$ & $\begin{array}{l}\text { Bir dekar alan için } 2000-3000 \text { ml ürün } 100 \\
\text { lt suyla karıştırılır ve yapraktan uygulanır. }\end{array}$ \\
\hline $\begin{array}{l}\text { Humica } \\
\text { Power }\end{array}$ & $\begin{array}{l}\text { Organik maddeyle birlikte koyu renkli humik/fulvik asit içeren sıvı } \\
\text { bir organomineral gübredir. }\end{array}$ & $\begin{array}{l}\text { Bir dekar alan için } 200-250 \mathrm{ml} \text { ürün } 100 \mathrm{lt} \\
\text { suyla karıştırılır ve yapraktan uygulanır. }\end{array}$ \\
\hline
\end{tabular}

Hasat edilen yaş bitkiler $35{ }^{\circ} \mathrm{C}$ sıcaklıkta 48 saat süre ile etüvde kurutulmuştur. Her bir uygulama için kurutulmuş yapraklardan 3 tekerrürlü olarak alınan örneklerde uçucu yağ oranları Clevenger cihazı kullanılarak su distilasyonu yöntemiyle belirlenmiștir. Uçucu yağların distilasyonu için ayıklanmış ve kurutulmuş 100 g yaprak örnekleri 2000 ml'lik balonlara yerleştirildikten sonra $1000 \mathrm{ml}$ saf su eklenerek 3 saat boyunca distilasyon işlemi gerçekleştirilmiştir. Distilasyon işlemi tamamlandıktan sonra clevenger aparatının dereceli kısmından yağ miktarı okunarak \% olarak belirlenmiştir. Uçucu yağlar bileșen analizine kadar $3-4{ }^{\circ} \mathrm{C}$ 'de buzdolabında saklanmıştır.

Uçucu yağ bileşimi GC-MS (Gaz KromatografisiKütle Spektrometresi) ile belirlenmiştir. Örnekler ilk önce 1:100 oranında hekzan ile seyreltilmiştir. Uçucu yağ örneklerinin bileşen analizi GC/GC-MS (Gaz kromatografisi (Agilent 7890A)-kütle detektör (Agilent 5975C)) cihazı ve kapiler kolon (HP InnowaxCapillary; $60.0 \mathrm{~m} \times 0.25 \mathrm{~mm} \times 0.25 \mu \mathrm{m})$ kullanılarak yapılmıştır. Taşıyıcı gaz olarak analizde $0,8 \mathrm{ml} / \mathrm{dk}$ akış hızında helyum kullanılarak, numuneler $1 \mu$ l olarak 40:1 split oranı ile cihaza enjekte edilmiştir. Enjektör sıcaklığı 250 ${ }^{\circ} \mathrm{C}$ 'ye ayarlanmıştır. Çalışma programı $60{ }^{\circ} \mathrm{C} \quad(10$ dakika), $60{ }^{\circ} \mathrm{C}$ 'den $250{ }^{\circ} \mathrm{C}$ 'ye $20^{\circ} \mathrm{C} /$ dakika ve $250^{\circ} \mathrm{C}$ (10,5 dakika) olacak şekilde planlanmıştır. Bu sıcaklık programı koşullarında 30 dakika toplam analiz süresi olmuştur. Kütle detektörü için tarama aralığ $(\mathrm{m} / \mathrm{z}) 35$ 450 atomik kütle ünitesi ve elektron bombardımanı iyonizasyonu $70 \mathrm{eV}$ kullanılmış, uçucu yağ bileşenleri teşhisinde WILEY ve OIL ADAMS kütüphane verileri esas alınmıştır. FID dedektör kullanılarak sonuçların bileşen yüzdeleri, MS dedektör kullanılarak bileşenlerin teşhisi yapılmışıtır.

Çalışmada yıl içindeki biçimler birleştirilerek elde edilen değerler, Tesadüf Bloklarında Bölünmüş Parseller Deneme Desenine göre analiz edilmiştir (Telci et al., 2010). Verilerin analizi SPSS istatistiksel yazılım proğramında yapılmış, önemli bulunan farklılıklar TUKEY karşılaştırma testi ile gruplandırılmıştır.

\section{Bulgular ve Tartışma}

Mentha spicata ve Mentha $x$ piperita türlerine uygulanan organik gübreler uçucu yağ oranı hariç incelenen diğer tüm özellikler üzerinde istatistiksel olarak önemli farklılığa sebep olmuştur. Mentha spicata türünde yılların etkisi incelenen tüm özellikler, Mentha x piperita türünde uçucu yağ oranı hariç diğer incelenen özellikler üzerine istatistiksel olarak önemli bulunmuştur. Y1l x organik gübre interaksiyonu Mentha spicata türünde bitki boyu hariç incelenen özellikler üzerine, Mentha x piperita türünde sadece uçucu yağ verimi üzerinde istatistiksel olarak önemli olmuştur (Çizelge 4, 5, 6, 7, 8 ve 9).

Mentha spicata'da bitki boyu değerleri 2018 ve 2019 yıllarında sirasıyla $51.84 \mathrm{~cm}$ ve $34.97 \mathrm{~cm}$ olarak belirlenirken, Mentha x piperita'da sirasiyla $37.42 \mathrm{~cm}$ ve $21.83 \mathrm{~cm}$ olarak belirlenmiştir (Çizelge 4). Bu durum ilkbaharda bitkilerin aktif büyümeye başladığı ilk aylar olan Nisan-Mayıs aylarında sıcaklık değerlerinin 2018 yılında 2019 yılına göre daha fazla olmasindan ve her iki türün buna olumlu tepki vermesinden kaynaklanmıştır (Tuğay ve ark., 2000). Bitki boyunu etkileyen en önemli faktörün kullanılan bitkisel materyalin genetik yapısı olduğu ancak çevresel faktörlerin de bitki boyunu etkilediği bildirilmiş̧ir (Baloch et al., 2010). Farklı organik gübre uygulamasının iki yıllık ortalama değerleri incelendiğinde, Mentha spicata ve Mentha x piperita türünde en yüksek bitki boyu sırasıyla $47.25 \mathrm{~cm}$ ve $31.55 \mathrm{~cm}$ olarak Lifebac-Np uygulamasinda ölçülmüştür. Her iki nane türünde kontrol uygulamasına göre organik gübre uygulamalarında bitki boyu önemli derecede artış göstermiştir. Mentha spicata türüne uygulanan Lifebac-Np uygulamasında bitki boyu önemli derecede artış göstermiş, Mentha x piperita türünde ise tüm organik gübre uygulamaları istatistiksel 
olarak aynı grupta yer almıştır (Çizelge 4). Benzer bitki boyunun arttı̆̆ı rapor edilmiştir (Mahboobeh et al., olarak organik gübre uygulaması ile nane türlerinde

Çizelge 4. Farklı organik gübre uygulamalarının Mentha x piperita ve Mentha spicata türlerinin bitki boyu üzerine etkisine ait ortalama değerler $(\mathrm{cm})$ ve varyans analiz sonuçları

Table 4. The results of variance analysis and mean values $(\mathrm{cm})$ of the effect of different organic fertilizer applications on the plant height in Mentha x piperita and Mentha spicata species

\begin{tabular}{|c|c|c|c|c|c|c|}
\hline \multirow{2}{*}{ Organik gübre } & \multicolumn{3}{|c|}{ Mentha spicata } & \multicolumn{3}{|c|}{ Mentha $\times$ piperita } \\
\hline & 2018 & 2019 & Ortalama & 2018 & 2019 & Ortalama \\
\hline Kontrol & 46.23 & 31.18 & $38.71 \mathrm{c}$ & 33.27 & 18.62 & $25.95 \mathrm{~b}$ \\
\hline Lifebac-Np & 56.20 & 38.30 & $47.25 \mathrm{a}$ & 39.62 & 23.47 & 31.55 a \\
\hline Bactoguard & 52.72 & 35.00 & $43.86 \mathrm{~b}$ & 39.20 & 22.60 & 30.90 a \\
\hline Humica Power & 52.20 & 35.38 & $43.79 \mathrm{~b}$ & 37.58 & 22.62 & 30.10 a \\
\hline Ortalama & $51.84 \mathrm{~A}$ & $34.97 \mathrm{~B}$ & 43.40 & $37.42 \mathrm{~A}$ & $21.83 \mathrm{~B}$ & 29.62 \\
\hline F değeri (yıl) & \multicolumn{3}{|c|}{$119.542 * *$} & \multicolumn{3}{|c|}{$168.793^{* *}$} \\
\hline F değeri (organik gübre) & \multicolumn{3}{|c|}{$38.213 * *$} & \multicolumn{3}{|c|}{$41.529 * *$} \\
\hline F değeri (yıl x o. gübre) & \multicolumn{3}{|c|}{$1.308 \mathrm{~ns}$} & \multicolumn{3}{|c|}{$1.147 \mathrm{~ns}$} \\
\hline CV (\%) & \multicolumn{3}{|c|}{21.68} & \multicolumn{3}{|c|}{28.32} \\
\hline
\end{tabular}

2014; Sheykholeslami et al., 2015; Keshavarz ve Modarres Sanavy, 2018).

Toplam taze herba verimi Mentha spicata türünde 2018 y1linda $2269.40 \mathrm{~kg} \mathrm{da}{ }^{-1}, 2019$ y1linda 1683.80 $\mathrm{kg} \mathrm{da}^{-1}$ olmuştur. Mentha x piperita türünde ise 2018 yılında $2051.40 \mathrm{~kg} \mathrm{da}^{-1}$ olarak belirlenirken, 2019 y1lında $1252.20 \mathrm{~kg} \mathrm{da}^{-1}$ olarak belirlenmiştir (Çizelge 5). İki yıl arasındaki verim farklılığ 1 yıllar arasındaki sıcaklık gibi iklim faktörlerinin değişmesinden ileri gelmektedir (Tuğay ve ark., 2000; Telci ve Şahbaz, 2005b). Nitekim ilkbaharda bitkilerin aktif büyümeye başladığı ilk aylar olan Nisan ve Mayıs aylarındaki ortalama sıcaklık değerleri 2018 yılında (sırasıyla $15.4^{\circ} \mathrm{C}$ ve $17.2^{\circ} \mathrm{C}$ ) 2019 yilina (sirasiyla $10.5^{\circ} \mathrm{C}$ ve $16.7^{\circ} \mathrm{C}$ ) kıyasla daha fazla olmuş, bu durum bitkilerin 2018 yılında hızlı büyüme ve gelişme göstermelerine neden olmuştur (Can, 2020). Mentha spicata'da en yüksek taze herba verimi yıllar ortalamasinda Lifebac-Np (2112.50 kg da-1) uygulamasından elde edilirken bunu sirasıyla Bactoguard (2079.25 kg da ${ }^{-1}$ ) ve Humica Power (2039.08 kg da-1) uygulamaları takip etmiştir. Mentha $x$ piperita'da ise en yüksek taze herba verimi yillar ortalamasında Lifebac-Np (1943.71 kg $\mathrm{da}^{-1}$ ) uygulamasından alınırken, Bactoguard ve Humica Power uygulamasindan sirasiyla $1734.00 \mathrm{~kg} \mathrm{da}^{-1}$ ve $1616.75 \mathrm{~kg} \mathrm{da}^{-1}$ taze herba verimi alınmıştır. Fakat Mentha spicata türünde tüm organik gübre uygulamaları taze herba verimi üzerine önemli bir farklılık göstermemiş, tüm uygulamalar aynı istatistiki grupta yer almıştır (Çizelge 5).

Çizelge 5. Farklı organik gübre uygulamalarının Mentha x piperita ve Mentha spicata türlerinin toplam taze herba verimi üzerine etkisine ait ortalama değerler $\left(\mathrm{kg} \mathrm{da}^{-1}\right)$ ve varyans analiz sonuçları

Table 5. The results of variance analysis and mean values $\left(\mathrm{kg} \mathrm{da}^{-1}\right)$ of the effect of different organic fertilizer applications on the total fresh herbage yield in Mentha x piperita and Mentha spicata species

\begin{tabular}{|c|c|c|c|c|c|c|}
\hline \multirow{2}{*}{ Organik gübre } & \multicolumn{3}{|c|}{ Mentha spicata } & \multicolumn{3}{|c|}{ Mentha $\times$ piperita } \\
\hline & 2018 & 2019 & Ortalama & 2018 & 2019 & Ortalama \\
\hline Kontrol & $1952.83 \mathrm{c}$ & $1398.00 \mathrm{~b}$ & $1675.42 \mathrm{~b}$ & 1717.83 & 907.67 & $1312.75 \mathrm{~d}$ \\
\hline Lifebac-Np & 2527.33 a & $1697.67 \mathrm{a}$ & $2112.50 \mathrm{a}$ & 2344.42 & 1543.00 & $1943.71 \mathrm{a}$ \\
\hline Bactoguard & 2323.17 b & 1835.33 a & 2079.25 a & 2160.67 & 1307.33 & $1734.00 \mathrm{~b}$ \\
\hline Humica Power & 2274.17 b & $1804.00 \mathrm{a}$ & 2039.08 a & 1982.50 & 1251.00 & $1616.75 \mathrm{c}$ \\
\hline Ortalama & $2269.40 \mathrm{~A}$ & $1683.80 \mathrm{~B}$ & 1976.60 & $2051.40 \mathrm{~A}$ & 1252.20 B & 1651.80 \\
\hline F değeri (y1l) & & $606.014^{* *}$ & & & $130.868 * *$ & \\
\hline F değeri (organik gübre) & & $89.911 * *$ & & & $89.673 * *$ & \\
\hline F değeri (y1l x o. gübre) & & $15.164 * *$ & & & $0.823 n s$ & \\
\hline CV (\%) & & 18.26 & & & 28.99 & \\
\hline
\end{tabular}

$*: \mathrm{p} \leq 0.05$ düzeyinde önemli, **: $\mathrm{p} \leq 0.01$ düzeyinde önemli, ns: önemli değil 
Toplam kuru herba verimi Mentha spicata türünde 2018 y1lında $\left(756.14 \mathrm{~kg} \mathrm{da}^{-1}\right) 2019$ yilından $\left(503.60 \mathrm{~kg} \mathrm{da}^{-1}\right)$ daha yüksek olmuştur. Mentha $x$ piperita türünde ise toplam kuru herba verimi 2018 y1lında $675.44 \mathrm{~kg} \mathrm{da}^{-1}$ olarak tespit edilirken, 2019 y1lında $380.05 \mathrm{~kg} \mathrm{da}^{-1}$ olarak tespit edilmiştir (Çizelge 6). Taze herba verimi tartışma bölümünde açıklandığı gibi 2018 yılında taze herba veriminin yüksek alınmasına etki eden sebepler dolayısıyla kuru herba veriminin de yüksek alınmasına neden olmuştur. Mentha spicata'da en yüksek kuru herba verimi y1llar ortalamasinda Humica Power (678.70 $\mathrm{kg} \mathrm{da}^{-1}$ ) uygulamasından elde edilirken bunu sirasiyla Lifebac-Np (666.19 $\left.\mathrm{kg} \mathrm{da}^{-1}\right)$ ve Bactoguard (660.22 $\mathrm{kg} \mathrm{da}^{-1}$ ) uygulamaları takip etmiştir. Mentha $\mathrm{x}$ piperita'da ise en yüksek kuru herba verimi yıllar ortalamasında Lifebac-Np (621.79 $\left.\quad \mathrm{kg} \quad \mathrm{da}^{-1}\right)$ uygulamasından alınırken, Bactoguard ve Humica Power uygulamasindan sirasiyla $573.73 \mathrm{~kg} \mathrm{da}^{-1}$ ve $511.75 \mathrm{~kg} \mathrm{da}^{-1} \mathrm{kuru}$ herba verimi alınmıştır. Bununla birlikte, Mentha spicata türünde tüm organik gübre uygulamaları kuru herba verimi üzerinde önemli bir farklılığa sebep olmamış, tüm uygulamalar aynı istatistiki grupta yer almıştır (Çizelge 6). Kaplan ve ark. (2009) Salvia officinalis L. ve Gerami et al. (2016) Origanum vulgare L. ile yaptıkları çalışmalarda benzer olarak organik gübre uygulaması ile taze herba verimi ve kuru herba veriminin arttığını bildirmişlerdir.

Çizelge 6. Farklı organik gübre uygulamalarının Mentha x piperita ve Mentha spicata türlerinin toplam kuru herba verimi üzerine etkisine ait ortalama değerler $\left(\mathrm{kg} \mathrm{da}^{-1}\right)$ ve varyans analiz sonuçları

Table 6. The results of variance analysis and mean values $\left(\mathrm{kg} \mathrm{da}^{-1}\right)$ of the effect of different organic fertilizer applications on the total dry herbage yield in Mentha x piperita and Mentha spicata species

\begin{tabular}{ccccccc}
\hline \multirow{2}{*}{ Organik gübre } & \multicolumn{3}{c}{ Mentha spicata } & \multicolumn{3}{c}{ Mentha x piperita } \\
& 2018 & 2019 & Ortalama & 2018 & 2019 & Ortalama \\
\hline Kontrol & $624.12 \mathrm{~b}$ & $404.62 \mathrm{~b}$ & $514.37 \mathrm{~b}$ & 543.55 & 263.85 & $403.70 \mathrm{~d}$ \\
Lifebac-Np & $822.61 \mathrm{a}$ & $509.78 \mathrm{a}$ & $666.19 \mathrm{a}$ & 778.65 & 464.92 & $621.79 \mathrm{a}$ \\
Bactoguard & $768.43 \mathrm{a}$ & $552.02 \mathrm{a}$ & $660.22 \mathrm{a}$ & 733.55 & 413.90 & $573.73 \mathrm{~b}$ \\
Humica Power & $809.40 \mathrm{a}$ & $547.99 \mathrm{a}$ & $678.70 \mathrm{a}$ & 645.99 & 377.52 & $511.75 \mathrm{c}$ \\
Ortalama & $756.14 \mathrm{~A}$ & $503.60 \mathrm{~B}$ & 629.87 & $675.44 \mathrm{~A}$ & $380.05 \mathrm{~B}$ & 527.74 \\
F değeri (y1l) & & $114.173^{* *}$ & & & $216.013^{* *}$ & \\
F değeri (organik gübre) & & $44.486^{* *}$ & & & $71.946^{* *}$ & \\
F değeri (y1l x o. gübre) & & $3.782^{*}$ & & & $3.282 \mathrm{~ns}$ & \\
CV (\%) & & 23.87 & & & 3.11 & \\
\hline
\end{tabular}

*: $\mathrm{p} \leq 0.05$ düzeyinde önemli, ${ }^{* *}: \mathrm{p} \leq 0.01$ düzeyinde önemli, ns: önemli değil

Çalıșmada kullanılan organik gübrelerden Lifebac-Np gübresi materyal ve yöntem bölümünde de belirtildiği üzere doğal bir Bacillus subtilis ve Bacillus megaterium izolatı içeren mikrobiyal bir gübredir. Biyogübreler olarak da isimlendirilebilen ve faydalı bakterileri içeren mikrobiyal gübreler, bitkilerin ihtiyaç duyduğu besin elementlerinin biyolojik yolla faydalı hale gelmesini sağlayarak, bitkisel hormonları üreterek, bitki metabolizmasını etkileyerek ve bazı zararlı patojenleri kontrol ederek bitki büyüme ve gelişimine katkıda bulunmaktadırlar (Ping ve Boland 2004; Parlak ve Güner 2017). Mikrobiyal gübreden daha yüksek verim alınması içeriğindeki Bacillus spp. bakterilerinin oksin ve sitokinin gibi fitohormonları sentezleyebilme yetenekleri ile açıklanabilir (Castanheira et al., 2013; $\mathrm{Li}$ et al., 2016). Nitekim köklendirme hormonu olarak bilinen oksinin, bitkide sitokinin düzeyine bağlı olarak kök gelişimini arttırdığı (Davies, 2010; Taiz ve Zeiger, 2010), sitokinin uygulamasının ise bitkilerde sürgün büyümesini teşvik ederek toplam biyokütlede artışa neden olduğu bildirilmiştir (Zahir et al., 2001; Liu et al., 2002). Bulgularımız, Bacillus bakterilerinin uygulanması ile bitki gelișimi ve veriminde artış olduğunu rapor eden Esitken et al. (2003), Gardener (2004), Karlidag et al. (2007) ve Tozlu et al. (2012) ile uyum sağlamaktadır.

Çalışmada toplam kuru yaprak verimi y1llar ortalamasında Mentha spicata türünde 266.56-333.86 $\mathrm{kg} \mathrm{da}^{-1}$ arasında alınırken, Mentha x piperita türünde 230.01-361.35 kg da ${ }^{-1}$ arasında alınmıştır. Diğer verimlere benzer şekilde 2018 yılında kuru yaprak verimleri 2019 yılından yüksek bulunmuştur. Mentha spicata türünde yıl $\mathrm{x}$ organik gübre interaksiyonu değerleri incelendiğinde, 2018 yılında en yüksek kuru yaprak verimi $386.19 \mathrm{~kg} \mathrm{da}^{-1}$ ile Lifebac-Np uygulamasından alınırken, 2019 yılında $298.91 \mathrm{~kg}$ da- ${ }^{1}$ ile Bactoguard uygulamasından alınmıştır. Yıllar ortalamasında ise en yüksek kuru yaprak verimleri Mentha spicata'da $333.86 \mathrm{~kg} \mathrm{da}^{-1}$ ve Mentha $x$ piperita'da $361.35 \mathrm{~kg} \mathrm{da}^{-1}$ olmak üzere Lifebac-Np uygulamasından elde edilmiştir. Bununla birlikte taze ve kuru herba veriminde olduğu gibi Mentha spicata türünde tüm organik gübre uygulamaları aynı istatistiki grupta yer almıştır (Çizelge 7). Sülü (2010) Mentha spicata'da toplam kuru yaprak verimini 
Tokat-Kazova koşullarında 208.5-426.8 $\mathrm{kg}_{\mathrm{da}}{ }^{-1}$ arasında, Yasak ve Telci (2019) Isparta koşullarında 295.8-386.9 $\mathrm{kg} \quad \mathrm{da}^{-1}$ arasinda elde ettiklerini bildirmişlerdir. Mentha x piperita türünde ise toplam kuru yaprak verimini Sülü (2010) 317.0-329.1 kg da-1 arasinda, Soltanbeig1 (2014) 330.7-491.2 $\mathrm{kg} \mathrm{da}^{-1}$ arasında belirlemişlerdir.

Çizelge 7. Farklı organik gübre uygulamalarının Mentha x piperita ve Mentha spicata türlerinin toplam kuru yaprak verimi üzerine etkisine ait ortalama değerler $\left(\mathrm{kg} \mathrm{da}^{-1}\right)$ ve varyans analiz sonuçları

Table 7. The results of variance analysis and mean values $\left(\mathrm{kg} \mathrm{da}^{-1}\right)$ of the effect of different organic fertilizer applications on the total dry leaf yield in Mentha x piperita and Mentha spicata species

\begin{tabular}{ccccccc}
\hline \multirow{2}{*}{ Organik gübre } & \multicolumn{3}{c}{ Mentha spicata } & \multicolumn{3}{c}{ Mentha x piperita } \\
& 2018 & 2019 & Ortalama & 2018 & 2019 & Ortalama \\
\hline Kontrol & $299.59 \mathrm{c}$ & $233.54 \mathrm{~b}$ & $266.56 \mathrm{c}$ & 290.96 & 169.05 & $230.01 \mathrm{c}$ \\
Lifebac-Np & $386.19 \mathrm{a}$ & $281.53 \mathrm{a}$ & $333.86 \mathrm{a}$ & 448.05 & 274.65 & $361.35 \mathrm{a}$ \\
Bactoguard & $352.66 \mathrm{~b}$ & $298.91 \mathrm{a}$ & $325.78 \mathrm{a}$ & 394.50 & 245.82 & $320.16 \mathrm{~b}$ \\
Humica Power & $342.34 \mathrm{~b}$ & $287.34 \mathrm{a}$ & $314.84 \mathrm{ab}$ & 354.25 & 231.65 & $292.95 \mathrm{~b}$ \\
Ortalama & $345.20 \mathrm{~A}$ & $257.33 \mathrm{~B}$ & 310.26 & $371.94 \mathrm{~A}$ & $230.29 \mathrm{~B}$ & 301.12 \\
F değeri (yıl) & & $100.715^{* *}$ & & & $348.822^{* *}$ & \\
F değeri (organik gübre) & & $85.571^{* *}$ & & & $59.756^{* *}$ & \\
F değeri (y1l x o. gübre) & & $13.377^{* *}$ & & & $2.967 \mathrm{~ns}$ & \\
CV (\%) & & 15.38 & & & & \\
\hline
\end{tabular}

*: $\mathrm{p} \leq 0.05$ düzeyinde önemli, ${ }^{* *}: \mathrm{p} \leq 0.01$ düzeyinde önemli, ns: önemli değil

Çalışmada elde ettiğimiz bulgular söz konusu araştırıcıların belirledikleri kuru yaprak verimi değerleri ile benzer sınırlar içerisinde kalmıştır.

Uçucu yağ oranı açısından sadece Mentha spicata türünde yıllar arasındaki farklılığın istatistiksel olarak önemli olduğu belirlenmiştir. Mentha spicata türünde organik gübre uygulamalarının ortalaması 2019 yılında (\% 1.97) 2018 yılına (\% 1.80) kiyasla daha yüksek ölçülmüştür (Çizelge 8). Bu durum 2019 yılı Haziran ayı (birinci biçim zamanı) ortalama sıcaklık değerinin $\left(20.9^{\circ} \mathrm{C}\right) 2018$ yılı aynı dönemine göre $\left(20.2^{\circ} \mathrm{C}\right)$ daha fazla olmasının uçucu yağ sentezine pozitif etki yapması ile açıklanabilir (Can, 2020). Her iki nane türünde organik gübre uygulamalarının uçucu yağ oranı üzerinde önemli bir etkisi olmamıştır. Bununla birlikte en yüksek uçucu yağ oranı Mentha spicata'da \% 1.94 ile Lifebac-Np uygulamasinda, Mentha x piperita'da ise \% 2.24 ile Humica Power uygulamasında tespit edilmiştir (Çizelge 8). Konu ile ilgili yapılan çalışmalarda Mentha türlerinde organik gübrenin uçucu yağ oranını önemli derecede $\operatorname{arttırdığ~} \breve{g}_{1}$ bildirilmiştir (Mahboobeh et al., 2014; Sheykholeslami et al., 2015; Sheykholeslami ve Almdari, 2019). Bu durum çalışmalarda kullanılan organik gübrelerin içeriği, kullanma dozu ve uygulama şeklinin farklı olması ile izah edilebilir. Benzer şekilde Keshavarz ve Modarres Sanavy (2018) organik gübre uygulamas1 ile uçucu yağ oranının önemli derecede değişmediğini rapor etmiştir.

Çizelge 8. Farklı organik gübre uygulamalarının Mentha x piperita ve Mentha spicata türlerinin uçucu yağ oranı üzerine etkisine ait ortalama değerler (\%) ve varyans analiz sonuçları

Table 8. The results of variance analysis and mean values (\%) of the effect of different organic fertilizer applications on the essential oil content in Mentha x piperita and Mentha spicata species

\begin{tabular}{ccccccc}
\hline Organik gübre & 2018 & 2019 & Ortalama & 2018 & 2019 & Ortalama \\
\hline Kontrol & $1.63 \mathrm{~b}$ & 1.96 & 1.79 & 2.38 & 2.00 & 2.19 \\
Lifebac-Np & $1.99 \mathrm{a}$ & 1.89 & 1.94 & 2.36 & 2.08 & 2.22 \\
Bactoguard & $1.82 \mathrm{ab}$ & 2.02 & 1.92 & 2.31 & 2.08 & 2.20 \\
Humica Power & $1.76 \mathrm{~b}$ & 2.02 & 1.89 & 2.29 & 2.19 & 2.24 \\
Ortalama & $1.80 \mathrm{~B}$ & $1.97 \mathrm{~A}$ & 1.89 & 2.34 & 2.09 & 2.21 \\
F değeri (yil) & & $633.373^{* *}$ & & & $13.420 \mathrm{~ns}$ \\
F değeri (organik gübre) & & $2.521 \mathrm{~ns}$ & & & $0.454 \mathrm{~ns}$ \\
F değeri (yıl x o. gübre) & & $5.378^{*}$ & & & $2.568 \mathrm{~ns}$ \\
CV (\%) & & 8.63 & & & \\
\end{tabular}

*: $\mathrm{p} \leq 0.05$ düzeyinde önemli, ${ }^{* *}: \mathrm{p} \leq 0.01$ düzeyinde önemli, ns: önemli değil 
Toplam uçucu yağ verimi Mentha spicata türünde 2018 y1lında 4.87-7.46 l da-1, 2019 y1lında 4.66-6.28 l $\mathrm{da}^{-1}$ arasında değişmiştir. Mentha $x$ piperita türünde ise toplam uçucu yağ verimi 2018 yılında 6.93-10.59 $1 \mathrm{da}^{-1}$ ve 2019 y1linda 3.42-5.98 $\mathrm{l} \mathrm{da}^{-1}$ arasinda belirlenmiştir. Mentha spicata'da yıl ortalamaları 2018 yllinda $6.17 \mathrm{l} \mathrm{da}^{-1}$ ve 2019 yilında $5.58 \mathrm{l} \mathrm{da}^{-1}$ olarak belirlenmiş, Mentha x piperita'da bu değerler sırasıyla $8.681 \mathrm{da}^{-1}$ ve $5.00 \mathrm{l} \mathrm{da}^{-1}$ olmuştur (Çizelge 9). Diğer verimlerde olduğu gibi uçucu yă veriminde de yıllar arasındaki fark önemli bulunmuştur. Her iki nane türünde 2018 y1lı kuru yaprak verimlerinin 2019 yılına göre daha yüksek olması 2018 yılı uçucu yağ veriminin de artışına sebep olmuştur. Yillar ortalamasında en yüksek uçucu yağ verimi hem Mentha spicata $\left(6.45 \mathrm{l} \mathrm{da}^{-1}\right)$ hem de Mentha x piperita'da (8.28 $\mathrm{l} \mathrm{da}^{-1}$ ) Lifebac-Np uygulamasından alınmıştır. Fakat Mentha spicata'da organik gübre uygulamaları önemli derecede farklılığa neden olmamıştır (Çizelge 9). Alsafar ve Al-Hassan (2009) artan gübreleme ile büyüme oranı arttığı için uçucu yağ veriminin de arttığını belirtmişlerdir. Keshavarz ve Modarres Sanavy (2018) İran koşullarında Mentha türlerine uyguladıkları organik gübre uygulamasında $13.91 \mathrm{da}$ 1 uçucu yă verimi elde etmişlerdir. Çalışmadan elde edilen uçucu yăg verimlerinin daha düşük olması kullanılan organik gübrelerin muhteviyatının ve uygulama şeklinin farklı olmasından kaynaklanmaktadır (Can, 2020).

Çizelge 9. Farklı organik gübre uygulamalarının Mentha x piperita ve Mentha spicata türlerinin toplam uçucu yağ verimi üzerine etkisine ait ortalama değerler $\left(\mathrm{L} \mathrm{da}^{-1}\right)$ ve varyans analiz sonuçları

Table 9. The results of variance analysis and mean values $\left(L \mathrm{da}^{-1}\right)$ of the effect of different organic fertilizer applications on the total essential oil yield in Mentha x piperita and Mentha spicata species

\begin{tabular}{|c|c|c|c|c|c|c|}
\hline \multirow{2}{*}{ Organik gübre } & \multicolumn{3}{|c|}{ Mentha spicata } & \multicolumn{3}{|c|}{ Mentha x piperita } \\
\hline & 2018 & 2019 & Ortalama & 2018 & 2019 & Ortalama \\
\hline Kontrol & $4.87 \mathrm{c}$ & $4.66 \mathrm{c}$ & $4.77 \mathrm{c}$ & $6.93 \mathrm{c}$ & $3.42 \mathrm{~b}$ & $5.18 \mathrm{c}$ \\
\hline Lifebac-Np & $7.46 \mathrm{a}$ & $5.45 \mathrm{~b}$ & $6.45 \mathrm{a}$ & 10.59 a & $5.98 \mathrm{a}$ & $8.28 \mathrm{a}$ \\
\hline Bactoguard & $6.34 \mathrm{~b}$ & $6.28 \mathrm{a}$ & $6.31 \mathrm{a}$ & 9.09 b & $5.30 \mathrm{a}$ & $7.20 \mathrm{~b}$ \\
\hline Humica Power & $6.00 \mathrm{~b}$ & $5.93 \mathrm{ab}$ & $5.96 \mathrm{ab}$ & $8.11 \mathrm{bc}$ & $5.31 \mathrm{a}$ & $6.71 \mathrm{~b}$ \\
\hline Ortalama & $6.17 \mathrm{~A}$ & $5.58 \mathrm{~B}$ & 5.87 & $8.68 \mathrm{~A}$ & $5.00 \mathrm{~B}$ & 6.84 \\
\hline F değeri (y1l) & \multicolumn{3}{|c|}{ 48.603* } & \multicolumn{3}{|c|}{$420.807 * *$} \\
\hline F değeri (organik gübre) & \multicolumn{3}{|c|}{$51.894 * *$} & \multicolumn{3}{|c|}{$51.220^{* *}$} \\
\hline F değeri (yıl x o. gübre) & \multicolumn{3}{|c|}{$20.040^{* *}$} & \multicolumn{3}{|c|}{$4.275^{*}$} \\
\hline CV (\%) & \multicolumn{3}{|c|}{15.10} & \multicolumn{3}{|c|}{32.89} \\
\hline
\end{tabular}

*: $\mathrm{p} \leq 0.05$ düzeyinde önemli, ${ }^{* *}: \mathrm{p} \leq 0.01$ düzeyinde önemli, ns: önemli değil

Birçok tıbbi ve aromatik bitkide olduğu gibi Mentha türlerinde de önemli bir kalite kriteri uçucu yağ oranının yanı sıra uçucu yağın kimyasal kompozisyonudur. Farklı organik gübre uygulamasında Mentha spicata türünde 37 farklı bileşen, Mentha x piperita türünde ise 36 farklı bileşen tespit edilmiştir (Çizelge 10 ve 11). Belirlenmiş olan bu bileşenler farklı organik gübrelere ve türlere bağlı olarak toplam uçucu yağın \% 99.00-100'lük kısmını oluşturmaktadır. Farklı organik gübre uygulamalarına göre Mentha spicata türünde carvone (\% 57.54-58.69) ve limonene (\% 17.20-18.65) ana bileşen olarak belirlenirken, Mentha $x$ piperita türünde ise menthol (\% 42.37-44.86) ve menthone (\%15.14-19.10) ana bileşen olarak belirlenmiştir (Çizelge 10 ve 11). Mentha spicata uçucu yağının bileşenleri içerisinde en yüksek oranda bulunan carvone farklı organik gübre uygulaması dikkate alınarak incelendiğinde, en yüksek oranda ( $\%$ 58.69) Humıca Power uygulamasında tespit edilirken, en düşük oranda ( $\%$ 57.54) kontrol uygulamasında tespit edilmiştir. Farklı organik gübre uygulamasında limonene oranının değişimi incelendiğinde, en yüksek limonene oranı $\left(\begin{array}{lll}\% & 18.65\end{array}\right)$ kontrol uygulamasında, en düşük limonene oranı ise (\% 17.20) Humıca Power uygulamasında belirlenmiştir (Çizelge 10). Mentha x piperita'da en yüksek menthol oranı Humica Power (\% 44.86) uygulamasından, en düşük menthol oranı Lifebac-Np (\% 42.37) uygulamasından elde edilmiştir. Farklı organik gübre uygulamasının Mentha x piperita'da menthone oranına etkisi incelendiğinde ise en yüksek menthone oranının (\% 19.10) Lifebac-Np uygulamasından, en düşük menthone oranının (\% 15.14) Humıca Power uygulamasından alındığ görülmektedir (Çizelge 11).

T1bbi ve aromatik bitkilerin etkili maddesi olan sekonder (biyoaktif) metabolitlerin bileşenleri çevre faktörlerinin, yetiştiricilik uygulamalarının ve üretim materyallerinin genotiplerine bağlı olarak değişiklik göstermektedir (Baher et al., 2002; Moradkhani et al., 2010). \% 55-65 oranında carvone içeren Mentha spicata uçucu yağının endüstriyel kullanım için uygun olduğu bildirilmiştir (Telci et al., 2004). Çalışmada farklı organik gübre uygulamalarına göre elde edilen carvone oranı değerlerinin bu değerlerin 
arasında olduğu görülmektedir (Çizelge 10). Bu çalışmada elde edilen carvone oranı değerleri, carvone oranların $\%$ 37.97-71.83 arasında tespit eden Sülü (2010) ile \% 49.70-61.50 arasında tespit eden Büyükbayraktar (2014)'ın değerleri arasında yer belirlemişlerdir. Çalışmadan elde edilen menthol oranı değerleri bu sınırlar arasında yer almaktadır. almaktadır. Mentha x piperita türünün uçucu yağında en önemli ana bileşen kuşkusuz mentholdür. Daha önce yapılan çalışmalarda Mentha x piperita türünde menthol oranını Telci et al. (2011) \% 30.87-44.19 arasında, Soltanbeigı (2014) ise \% 31.9-43.9 arasinda

Çizelge 10. Farklı organik gübre uygulamalarının Mentha spicata türünün uçucu yağ bileşimi üzerine etkisine ait ortalama değerler (\%)

Table 10. Mean values (\%) of the effect of different organic fertilizer applications on the essential oil composition in Mentha spicata species

\begin{tabular}{|c|c|c|c|c|c|}
\hline R.Time & Bileşenler & Kontrol & Lifebac-Np & Bactoguard & Humica Power \\
\hline 11.31 & $\alpha$-Pinene & 0.97 & 0.96 & 0.93 & 0.91 \\
\hline 14.71 & $\beta$-pinene & 1.36 & 1.32 & 1.31 & 1.26 \\
\hline 15.30 & Sabinene & 0.65 & 0.66 & 0.65 & 0.62 \\
\hline 17.11 & Myrcene & 3.21 & 3.36 & 3.33 & 3.21 \\
\hline 18.77 & Limonene & 18.65 & 17.81 & 17.61 & 17.20 \\
\hline 19.25 & 1.8-Cineole & 3.99 & 3.98 & 4.01 & 3.87 \\
\hline 26.36 & 3-Octanol & 0.11 & 0.06 & - & 0.07 \\
\hline 29.08 & Trans-sabinene hydrate & 0.94 & 1.21 & 1.20 & 1.11 \\
\hline 29.28 & $\gamma$-Terpinene & 0.59 & 0.60 & 0.54 & 0.55 \\
\hline 29.57 & L-Menthone & - & - & 0.13 & - \\
\hline 29.84 & cis-3-hexenyl isovalerate & 0.15 & - & - & 0.07 \\
\hline 31.29 & $\beta$-Bourbonene & 2.19 & 2.21 & 2.25 & 2.27 \\
\hline 32.24 & cis-Sabinene hydrate & - & 0.03 & 0.05 & 0.04 \\
\hline 32.42 & Menthyl acetate & 0.05 & - & 0.10 & - \\
\hline 32.88 & $\beta$-Cubebene & 0.07 & 0.06 & - & 0.06 \\
\hline 33.51 & $\beta$-Elemene & 0.72 & 0.78 & 0.82 & 0.77 \\
\hline 33.85 & beta-Caryophyllene & 1.62 & 1.53 & 1.64 & 1.68 \\
\hline 34.14 & cis-Dihydrocarvone & 0.42 & 0.28 & - & - \\
\hline 34.34 & trans-Dihydrocarvone & 0.43 & 0.70 & 1.16 & 1.09 \\
\hline 34.72 & L-Menthol & - & 0.13 & 0.35 & 0.23 \\
\hline 35.30 & Pulegone & 0.22 & 0.23 & 0.13 & 0.22 \\
\hline 35.73 & Dihydrocarvyl acetate & 0.41 & 0.36 & 0.39 & 0.41 \\
\hline 35.94 & bicyelosesquiphellandrene & 0.21 & 0.23 & 0.16 & 0.22 \\
\hline 36.13 & (+)-Epi-bicyclosesquiphellandrene & - & - & - & 0.10 \\
\hline 36.65 & $\alpha$-Terpineol & 0.24 & 0.19 & 0.09 & 0.25 \\
\hline 37.25 & Germacrene D & 2.07 & 2.39 & 2.51 & 2.34 \\
\hline 37.40 & Neodihydrocarveol & 0.77 & 0.72 & 0.80 & 0.90 \\
\hline 37.54 & cis-Carvyl Acetate & 0.05 & 0.06 & - & 0.06 \\
\hline 37.94 & Bicyclogermacrene & 0.44 & 0.51 & 0.53 & 0.50 \\
\hline 38.11 & Carvone & 57.54 & 58.23 & 57.97 & 58.69 \\
\hline 40.21 & Trans-Carveol & 0.33 & 0.27 & 0.26 & 0.38 \\
\hline 41.02 & cis-Carveol & 0.33 & 0.27 & 0.27 & 0.32 \\
\hline 43.37 & cis-Jasmone & - & - & - & 0.05 \\
\hline 44.99 & Caryophyllene oxide & - & 0.03 & - & 0.04 \\
\hline 46.09 & 1.10-di-epi-Cubenol & 0.04 & 0.04 & 0.04 & 0.08 \\
\hline
\end{tabular}




\begin{tabular}{cccccc}
\hline 47.93 & & & & 0.14 & 0.16 \\
50.06 & spathulenol & 0.19 & 0.22 & 0.04 & 0.05 \\
& $\alpha$-Cadinol & 0.04 & 0.04 & 99.43 & 99.77 \\
\hline
\end{tabular}

Çizelge 11. Farklı organik gübre uygulamalarının Mentha x piperita türünün uçucu yağ bileşimi üzerine etkisine ait ortalama değerler (\%)

Table 11. Mean values (\%) of the effect of different organic fertilizer applications on the essential oil composition in Mentha x piperita species

\begin{tabular}{|c|c|c|c|c|c|}
\hline R.Time & Bileşenler & Kontrol & Lifebac-Np & Bactoguard & Humica Power \\
\hline 11.31 & $\alpha$-Pinene & 0.77 & 0.79 & 0.76 & 0.79 \\
\hline 14.72 & $\beta$-pinene & 1.18 & 1.19 & 1.16 & 1.20 \\
\hline 15.30 & Sabinene & 0.66 & 0.66 & 0.64 & 0.67 \\
\hline 16.91 & $\beta$-myrcene & 0.14 & 0.21 & 0.15 & 0.19 \\
\hline 17.68 & $\alpha$-terpinene & - & - & 0.07 & 0.05 \\
\hline 18.75 & Limonene & 2.00 & 1.99 & 1.99 & 2.06 \\
\hline 19.25 & 1.8-Cineole & 6.51 & 6.27 & 6.43 & 6.65 \\
\hline 20.03 & $\beta$-Ocimene & - & 0.08 & 0.05 & - \\
\hline 20.33 & cis-Ocimene & 0.14 & - & 0.08 & 0.09 \\
\hline 21.96 & p-Cymene & 0.10 & 0.06 & 0.15 & 0.07 \\
\hline 26.36 & 3-Octanol & 0.20 & 0.20 & 0.16 & 0.23 \\
\hline 29.09 & Trans-sabinene hydrate & 1.33 & 1.76 & 1.08 & 1.41 \\
\hline 29.28 & $\gamma$-Terpinene & 1.06 & 1.01 & 1.23 & 1.03 \\
\hline 29.59 & Menthone & 17.65 & 19.10 & 16.92 & 15.14 \\
\hline 30.06 & Menthofurane & 1.66 & 1.81 & 1.66 & 1.80 \\
\hline 30.52 & Isomenthone & 2.77 & 3.00 & 2.72 & 2.59 \\
\hline 31.29 & $\beta$-Bourbonene & 0.44 & 0.46 & 0.43 & 0.40 \\
\hline 31.36 & Neomenthyl acetate & 0.19 & 0.18 & 0.21 & 0.33 \\
\hline 31.94 & Linalool & 0.14 & 0.09 & 0.15 & 0.08 \\
\hline 32.22 & cis-Sabinene hydrate & 0.17 & 0.14 & 0.17 & 0.17 \\
\hline 32.45 & Menthyl acetate & 4.88 & 4.74 & 5.26 & 6.27 \\
\hline 33.04 & Neoisomenthyl acetate & 0.17 & 0.16 & 0.08 & 0.14 \\
\hline 33.39 & Neomenthol & 3.33 & 3.28 & 3.47 & 3.84 \\
\hline 33.58 & b-Elemene & 1.21 & 1.32 & 1.57 & 1.44 \\
\hline 33.97 & $\beta$-caryophyllene & 3.42 & 3.17 & 3.56 & 3.21 \\
\hline 34.35 & Neoisomenthol & 0.78 & 0.74 & 0.82 & 0.84 \\
\hline 34.96 & Menthol & 43.68 & 42.37 & 44.13 & 44.86 \\
\hline 35.38 & (Z)- $\beta$-Farnesene & 0.40 & 0.38 & 0.38 & 0.36 \\
\hline 35.52 & Isomenthol & 0.22 & 0.21 & 0.22 & 0.32 \\
\hline 35.6 & Pulegone & 0.13 & 0.16 & 0.16 & 0.14 \\
\hline 36.75 & $\alpha$-Terpineol & 0.16 & 0.15 & 0.16 & 0.15 \\
\hline 37.25 & Germacrene D & 2.31 & 2.31 & 2.29 & 2.03 \\
\hline 37.76 & Piperitone & 0.65 & 0.64 & 0.63 & 0.55 \\
\hline 37.94 & Bicyclogermacrene & 0.28 & 0.25 & 0.43 & 0.43 \\
\hline 38.07 & Carvone & 0.21 & 0.13 & - & - \\
\hline 47.04 & Viridiflorol & 0.97 & 0.99 & 1.00 & 0.86 \\
\hline \multicolumn{2}{|r|}{ Toplam } & 99.89 & 99.96 & 100.00 & 100.00 \\
\hline
\end{tabular}




\section{Sonuç}

Türkiye'de özellikle baharat olarak Mentha spicata türünün daha çok kültürü yapılmakta, Mentha x piperita türünün ise uçucu yağ 1 (en önemli bileşenleri menthol ve menthon) dıs ticarete konu olmaktadır. Bu itibarla, çalışmada söz konusu iki önemli nane türünde farklı organik gübre uygulamalarının etkinliği araştırılmıştır. Elde edilen sonuçlara göre, çalışmada kullanılan tüm organik gübreler her iki nane türünde bitki boyu, toplam taze ve kuru herba verimi, kuru yaprak verimi ve uçucu yağ veriminde kontrol uygulamasina göre önemli derecede artıșa neden olmuștur. Her iki nane türünde en yüksek kuru yaprak ve uçucu yağ verimleri Lifebac-Np uygulamasından alınmıştır. Bununla birlikte uygulanan organik gübreler arasında toplam kuru yaprak ve uçucu yağ verimi bakımından Mentha $x$ piperita'da istatistiksel olarak önemli farklılık görülürken, Mentha spicata'da önemli farklılık görülmemiştir. Dünya'da organik tarım ürünlerine olan ilginin artmasına paralel olarak tıbbi ve aromatik bitkilerin de organik üretimi önem kazanmaktadır. Bu itibarla, nane gibi tıbbi ve aromatik bitkilerde organik gübre uygulamasının etkinliğinin daha kapsamlı bir şekilde araştırılması faydalı olacaktır.

\section{Teşekkür}

$\mathrm{Bu}$ makale Mustafa CAN'ın doktora tezinden türetilmiş olup, Eskişehir Osmangazi Üniversitesi Bilimsel Araştırma Projeleri Koordinatörlüğü tarafindan '2018-1985' no'lu proje ile desteklenmiştir. Desteklerinden dolayı Eskişehir Osmangazi Üniversitesi Bilimsel Araştırma Projeleri Koordinatörlügüu birimine teşekkür ederiz.

\section{Kaynaklar}

Alsafar, M.S., Al-Hassan, Y., 2009. Effect of nitrogen and phosphorus fertilizers on growth and oil yield of indigenous mint (M. longifolia L.) Biotechnology, 8(3):380-384. doi: 10.3923/biotech.2009.380.384.

Anonim, 2019. Türkiye İstatistik Kurumu, Dış Ticaret İstatistikleri.https://biruni.tuik.gov.tr/. Erişim Tarihi: 03.11.2019.

Baher, Z.F., Mirza, M., Ghorbanli, M., Rezaii, M.B., 2002. The influence of water stress on plant height, herbal and essential oil yield and composition in Satureja hortensis L. Flavour and Fragrance Journal, 17: 275-277. doi:10.1002/ffj.1097.

Bajeli, J., Tripathı, S., Kumar, A., Tripathı, A., Upadhyay, R.K., 2016. Organic manures a convincing source for quality production of japanese mint (Mentha arvensis L.). Ind Crop Prod, 83: 603606. doi :10.1016/j.indcrop.2015.12.064.

Baloch, M.S., Shah, I.T.H., Nadim, M.A., Khan, M.I., Khakwani, A.A., 2010. Effect of seeding density and planting time on growth and yield attributes of wheat. The Journal of Animal \& Plant Sciences, 20(4): 239-240.

Baydar, H., 2016. Tibbi ve aromatik bitkileri bilimi ve teknolojisi. Süleyman Demirel Üniversitesi Ziraat Fakültesi, Yayın No: 51, Beşinci bask1, Isparta.

Baytop, T., 1992. Türkçe bitki adları sözlüğü. Türk Dil Kurumu, Yayın No:578, Ankara.

Büyükbayraktar, A., 2014. Konya ekolojik şartlarında farklı azot dozlarında yetiştirilen Mentha piperita L. ve Mentha spicata L. türlerinin kurutma yöntemlerine göre drog verimi ve bazı kalite özelliklerinin araştırılması. Yüksek Lisans Tezi. Selçuk Üniversitesi Fen Bilimleri Enstitüsü, 48 s, Konya.

Can, M., 2020. Farklı organik gübre ve azot dozlarının Mentha x piperita L. ve Mentha spicata L. genotiplerinin tarımsal ve kalite özelliklerine etkisi. Doktora Tezi. Eskişehir Osmangazi Üniversitesi Fen Bilimleri Enstitüsü, 257 s, Eskișehir.

Castanheira, N., Dourado, A.C., Alves, P.I, CortesPallero, A.M, Delgado-Rodriguez, A.L., Prazeres, A., Borges, N., Sanchez, C., Crespo, M.T.B., Fareleira, P., 2013. Annual ryegrass-associated bacteria with potential for plant growth promotion. Microbiological Research, 169: 768-779. doi: 10.1016/j.micres.2013.12.010.

Davies, P.J., 2010. Plant hormones: Biosynthesis, signal trans-duction,action 3rd ed. Springer. New York. doi:10.1007/978-1-4020-2686-7.

Davis, P.H., 1982. Flora of Turkey and the East Aegean Islands. Vol:7. Edinburg Univ. Press.

Esitken, A., Pirlak, L., Turan, M., Şahin, F., 2006. Effect of floral an foliar application of plant growth promoting rhizobacteria (PGPR) on yield, growth and nutrition of sweet cherry. Scientia Horticulturae, 110: 324-327. doi: 10.1016/j.scienta.2006.07.023.

Gardener, M.C.B., 2004. Ecology of Bacillus and Paennibacillus spp. In Agricultural System. Department of Plant Pathology, The Ohio State University, OARDC, Wooster 44691. USA. Phytopathology, 1252-1258pp.

Gerami, F., Moghaddam, P.R., Ghorbanim, R., Hassani, A., 2016. Effects of irrigation intervals and organic manure on morphological traits essential oil content and yield of oregano (Origanum vulgare L.). Anais da Academia Brasileira de Ciências, 88(4): 23752385. doi:10.1590/0001-3765201620160208.

Hussain, A., Anjum, F., Rab, A., Sajid, M., 2006. Effects of nitrogen on the growth and yield of 
asparagus (Asparagus officinalis). Journal of Agricultural and Biological Science, 1(2):41-47.

Kaplan, M., Kocabaş, I., Sönmez, İ., Kalkan, H., 2009. The effects of different organic manure applications on the dry weight and the essential oil quantity of sage (Salvia fruticosa Mill.). Acta Horticulturae. 826:147-152. 10.17660/ActaHortic.2009.826.20.

Karlidag, H., Esitken, A., Turan, M., Sahin, F., 2007. Effects of root inoculation of plant growth promoting rhizobacteria (PGPR) on yield, growth and nutrient element contents of leaves of apple. Scientia Horticulturae. (114):16-20. doi:10.1016/j.scienta.2007.04.013.

Keshavarz, H., Modarres Sanavy, S.A.M., 2018. Yield and oil content of mint under different nitrogen fertilizer treatments. Notulae Scientia Biologicae, 10(1):92-96. doi: 10.15835/nsb10110221.

Li, X., Geng, X., Xie, R., Fu, L., Jiang, J., Gao, L., Sun, J., 2016. The endophytic bacteria isolated from elephant grass (Pennisetum purpureum Schumach) promote plant growth and enhance salt tolerance of hybrid pennisetum. Biotechnol Biofuels 9: 190-213. doi: 10.1186/s13068-016-0592-0.

Liu, X., Huang, B., Banowetz, G., 2002. Cytokinin effects on creeping bentrgrass responses to heat stress: I.Shoot and Root Growth. CropSci. 42: 457465. doi: 10.2135/cropsci2002.0466.

Mahboobeh, Z., Morteza, A.S., Mryam, T., Reza, S.A., 2014. Effects of organic and chemical fertilizers on quantitative and qualitative characteristics of peppermint (Mentha piperita L.). International Journal of Agriculture and Crop Sciences, 7(5):237244.

Moradkhani, H., Sargsyan, E., Bibak, H., Naseri, B., Sadat-Hosseini, M., Fayazi-Barjin, A., Meftahizade, H., 2010. Melissa officinalis L. a valuable medicine plant: A review. Journal of Medicinal Plants Research. 4(25):2753-2759. 29 December Special Review. ISSN 1996-0875 (C2010 Academic Journals

Nektarios, P.A., Petrovic, A.M., Steenhuis, T.S., 2014. Nitrate and tracer leaching from aerated turfgrass profiles. European Journal of Horticultural Science, 79: 150-157.

Nurzynska-Wierdak, R., 2013. Does mineral fertilization modify essential oil content and chemical composition in medicinal plants? Acta Sci. Pol., Hortorum Cultus. 12(5):3-16.

Özyiğit, Y., Uçar, E., Tütüncü, B., İndibi, İ., Turgut, K., 2016. The effect of different nitrogen doses on yield and some yield components of Melissa officinalis subsp. L. altissima (sibthr. et smith) Arcang. Turk J Agric Res, 3: 139-144. doi: 10.19159/tutad.79496.

Parlak, S., Güner, D., 2017. Mikrobiyal gübre uygulamasının karaçam (Pinus nigra Arnold. Subsp. Pallasiana (Lamb.) Holmboe) fidanlarının bazı morfolojik özelliklerine etkisi. Ormancılık Araştırma
Dergisi,
$4(2)$ :
100-106.
doi:

10.17568/ogmoad.337884.

Ping, L, Boland, W., 2004. Signals from the underground: Bacterial volatiles promote growh in Arabidopsis. Trends Plant Sci. 9: 263-266. doi: 10.1016/j.tplants.2004.04.008.

Rao, B.R., 2001. Biomass and essential oil yields of rainfed palmarosa (Cymbopogonmartinii (Roxb.) Wats. var. Motia Burk.) supplied with different levels of organic manure and fertilizer nitrogen in semi-arid tropical climate. Indusrial Crops and Product, 14:171-178. doi:10.1016/S09266690(01)00081-4

Sheykholeslami, Z., Almdari, M.Q., 2019. Comparison of the effect of organic and chemical fertilizers on yield and essence of peppermint (Mentha piperita L.). Current Journal of Applied Science and Technology. 34(5):1-7. doi: 10.9734/cjast/2019/v34i530146.

Sheykholeslami, Z., Qasempour Alari, M., Qanbari, S., Akbarzadeh, M., 2015. Effect of organic and chemical fertilizers on yield and yield components of peppermint (Mentha Piperita L.). Am. J. Exp. Agric. 6(4): 251-257. doi: 10.9734/AJEA/2015/14953.

Soltanbeıg1, A., 2014. Çukurova bölgesi marjinal arazi koşullarında Mentha türlerinde farklı dikim zamanlarının verim ve kaliteye etkisi. Doktora Tezi. Çukurova Üniversitesi Fen Bilimleri Enstitüsü, 145 s, Adana.

Sülü, E., 2010. Seçilmiş Nane (Mentha spp.) klonlarının Tokat şartlarında verim ve kalite özelliklerinin belirlenmesi. Yüksek Lisans Tezi. Gaziosmanpaşa Üniversitesi Fen Bilimleri Enstitüsü, 47 s, Tokat.

Taiz, L., Zeiger, E., 2010. Auxin: The first discovered plant growth hormone. In: L. Taiz and E. Zeiger. Editors. Plant physi-ology. 5thed. Sinauer Associates Inc. Publishers. Sunderland. MS. pp. 545-582.

Telci, İ., Demirtas, I., Bayram, E., Arabaci, O., Kacar, O., 2010. Environmental variation on aroma component of pulegone/piperitone rich spearmint (Mentha spicata L.). Industrial Crops and Products. 32:588-592. doi: 10.1016/j.indcrop.2010.07.009.

Telci, İ., Kacar, O., Bayram, E., Arabacı, O., Demirtaş, İ., Yılmaz, G., Özcan, İ., Sönmez, Ç., Göksu, E., 2011. The effect of ecological conditions on yield and quality traits of selected peppermint (Mentha piperita L.) clones. Industrial Crops and Products. 34: 1193-1197. doi: 10.1016/j.indcrop.2011.04.010.

Telci, İ., Şahbaz, N., 2005a. Variation of yield, essential oil and carvone contents in clones selected from carvone-scented landraces of Turkish Mentha species. Journal of Agronomy, 4(2):96-102. doi: 10.3923/ja.2005.96.102.

Telci, İ., Şahbaz, N., 2005b. Determination of agronomic and essential oil properties of peppermint (Mentha Piperita L.) in various ages of plantation. 
Journal of Agronomy. 4(2): 103-108.doi: 10.3923/ja.2005.103.108.

Telci, İ., Şahbaz, N., Yılmaz, G., Tugay, M.E., 2004. Agronomical and chemical characterization of spearmint (Mentha spicata L.) originating in Turkey. Economic Botany. 58:721-728.

Tozlu, E., Karagöz, K., Babagil, G.E., Dizikısa, T., Kotan, R., 2012. Effect of some plant growth promoting bacteria on yield, yield components of dry bean (Phaseolus vulgaris L.cv. Aras 98). Atatürk Univ. Journal of Agricultural Faculty, 43(2):101106. doi:10.17097/zfd.46922.

Tuğay, M.E., Kaya, N., Yılmaz, G., Telci, İ., Dönmez, E., 2000. Tokat ve Çevresinde Yaygın Olarak Bulunan Bazı Aromatik Bitkilerin Bitkisel ve Teknolojik Özellikleri. Tübitak. Tarım ve Ormancilık Araştırma Grubu. Proje Kesin Sonuç Raporu (Togtag-1690).

Tüik, 2019. Türkiye İstatistik Kurumu. http://www.tuik.gov.tr/. Erişim Tarihi:03.11.2019

Vessey, J.K., 2003. Plant growth promoting rhizobacteria as biofertilizers. Plant and Soil 255: 571-586.

Yasak, S., Telci, İ., 2019. Isparta ekolojik koşullarında yetiştirilen spearmint grubu nane klon ve çeşitlerinin verim performanslarının belirlenmesi. Ziraat Fakültesi Dergisi. 14(2):270-275.

Zahir, Z.A., Asghar, H.N., Arshad, M., 2001. Cytokinin and its precursors for improving growth and yield of rice. Soil Biology and Biochemistry, 33:405-408. doi:10.1016/S0038-0717(00)00145-0. 